\title{
CARE LABEL ISSUES OF SILK FABRIC
}

\author{
Swapan Kumar Ghosh ${ }^{1}$, Abir Baran Das ${ }^{2}$, Rajib Bhattacharyya ${ }^{3}$ \\ ${ }^{1}$ Associate Professor, Department of Jute and Fibre Technology, University of Calcutta, West Bengal, India \\ ${ }^{2}$ Quality Assurance Manager, J.J.Spectrum Silk, West Bengal, India \\ ${ }^{3}$ Senior Research Fellow, Department of Jute and Fibre Technology, University of Calcutta, West Bengal, India
}

\begin{abstract}
Silk fabrics emerge in a wide spectrum of popular products like silk satin, silk crepe de chine, silk georgette, silk chiffon, silk taffeta, silk scarves etc. Silk being a natural and delicate fibre demands certain caring treatments during its use in textiles, apparels in particular. Silk apparels and textiles, like the other textile products, get soiled due to repeated use. These products need to be refurbished for reuse without substantively altering their functional and aesthetic properties. National and international organizations coordinate their efforts to establish objective test methods for care label instructions. Correct care of silk products ensures retaining their quality for years. Care labels in apparels provide a useful information to the end users to look after their textile products made from different fibres. These labels are basically simple, space-saving, comprehensive pictorial symbols reducing the dependence on language and guiding the consumers to clean and maintain the product in the best possible way. Care instructions play a very vital role during laundering of the textile products, particularly silk, both domestically and commercially. This paper focusses the effects of care label codes like washing, laundering, dry cleaning, ironing, drying etc. on the different phenomena like deformation, colour change, colour staining of the plain weave 100\% silk fabric samples followed by the selection of the appropriate care code for greater durability and refurbishing of the fabric. Faulty laundering, boiling, steaming, uneven friction and stretching may damage the fabric quickly. The authors attempt to address these issues with the help of an intensive case study and recommend an ideal wash care method for silk apparels.
\end{abstract}

Keywords: Care label codes, washing, laundering, dry-cleaning, ironing, shrinkage, refurbishing

\section{INTRODUCTION}

Care labels provide guidelines to consumers and apparel care givers about the best cleaning procedures to be used for that particular combination of fabric, thread, decoration and construction techniques. Care codes are the internationally recognized symbols which are used for caring of garments in case of cleaning and ironing [1]. These labels on which these codes are drawn or printed are called care labels. Care label guideline delivers a uniform system of symbols for the disclosure of care instruction on textile products such as apparel, piece goods; etc. This guide furnishes a comprehensive system of symbols to represent care instructions in order to reduce language dependent care instructions [2]. Apparels and textiles are soiled during normal use. Economic realities require used items must be cleaned and refurbished for reuse without substantially altering their functional aesthetic properties [3]. A common concern in apparel performance characterization is the dimensional stability. Accelerated test methods are applied to wash and dry at the recommended conditions and careful measurement of any changes in dimensions determine the product ability to withstand the "care label" recommendations [4].

The U.S. Federal Trade Commission's care labeling rule requires manufacturers and importers to attach care instructions to garments [5]. Care labels must be permanently attached and remain legible for the life of the garment. Sometimes symbols may be used in conjunction with words. The life span of an apparel product is governed by many factors. Character of fibre, fabric construction, weight, and different mechanical and chemical finishing methods are some of them. Though it appears a little complicated to take right care of apparel in laundering due to the non-existence of a uniform capsule, but a systematic and scientific approach can resolve the issue effectively by adopting the appropriate procedure and following the exact technique. Deviation due to ignorance and negligence in some cases often leads to loss in aesthetic and functional significance of an apparel product and ultimately results in dissatisfaction [6]. It is well-known that silk apparel is delicate to laundering and demands scientific approach, appropriate procedure and techniques for proper refurbishing [6]. Silk will last for many years, as long as it is properly cared for and protected from heat, sunlight, perspiration, washing and harsh chemicals. Silk is a considerably strong natural fiber, having a beautiful drape and is naturally crease resistant. The drawback of silk is that it loses its strength when wet and therefore needs to be treated gently during laundering [7]. Retention of dimensional stability of a fabric is important during both washing and dry-cleaning. Major markets in the apparel trade can be broadly classified under two heads, US based and non US based [4]. General testing requirement regarding shrinkages after washing and dry cleaning is shown in table -1 . The potential damage to garments during cleaning is generally higher with aqueous media than with non-aqueous media [8]. This fact is the major reason why dry cleaning is so highly utilized. Often, manufacturers lowlabel their garments as "Dry Clean Only" to reduce garment damage and to ensure customer satisfaction during 
the use of their products [6]. The shrinkage requirement limit in apparel trade market US based and non US based varies from $-3 \%$ to $-4 \%$ and $+3 \%$ for warp as well as weft in woven goods, whereas permitted variation in knitted goods is $\pm 5 \%$ both in course and wales direction [4]. Similarly, in dry cleaning, tolerance in woven products vary from $\pm 2 \%$ to $\pm 2.5 \%$ for warp and weft and $\pm 2.5 \%$ to $\pm 3 \%$ for knits in course and wales direction.

Table-1: General requirements regarding shrinkage\% for major apparel markets

\begin{tabular}{|c|c|c|c|c|c|}
\hline \multirow[t]{2}{*}{ Countries } & & \multicolumn{2}{|l|}{ Washing } & \multicolumn{2}{|c|}{ Dry cleaning } \\
\hline & $\begin{array}{l}\text { Dimension } \\
\text { al Stability }\end{array}$ & $\begin{array}{l}\text { Woven } \\
\text { (warp } \\
\text { \& weft) }\end{array}$ & $\begin{array}{l}\text { Knitte } \\
\text { d } \\
\text { (lengt } \\
\text { h \& } \\
\text { width) }\end{array}$ & $\begin{array}{l}\text { Woven( } \\
\text { warp \& } \\
\text { weft) }\end{array}$ & $\begin{array}{l}\text { Knitted } \\
\text { (length } \\
\text { \& width) }\end{array}$ \\
\hline U.S. & $\begin{array}{l}\text { After } 3 / 5 \\
\text { wash }\end{array}$ & $-3.5 \% /+3 \%$ & $\pm 5 \%$ & $\pm 2.5 \%$ & $\pm 3 \%$ \\
\hline Canada & $\begin{array}{l}\text { After } 3 / 5 \\
\text { wash }\end{array}$ & $-3.5 \% /+3 \%$ & $\pm 5 \%$ & $\pm 2.5 \%$ & $\pm 3 \%$ \\
\hline U. K. & & $-4 \% /+3 \%$ & $\pm 5 \%$ & $\pm 2.5 \%$ & $\pm 3 \%$ \\
\hline Europe & & $-4 \% /+3 \%$ & $\pm 5 \%$ & $\pm 2.5 \%$ & $\pm 3 \%$ \\
\hline Australia & & $-3.5 \% /+3 \%$ & $\pm 5 \%$ & $\pm 2.5 \%$ & $\pm 2.5 \%$ \\
\hline
\end{tabular}

Ironing, pressing and finishing are the terms, which are often used interchangeably [9]. The basic aim of these different activities is to remove the "unwanted" crease and impart "wanted" crease. Ironing involves relative movement or friction between two flat surfaces, while pressing involves compression between two surfaces with no relative motion between them. Finishing remove the "unwanted" crease by starching but cannot impart a "wanted" crease [9]. There are five basic symbols: washtub, triangle, square, iron, and circle. The washtub represents the washing process, the triangle represents the bleaching process, the square represents the drying process, the iron represents the ironing or pressing process and the circle represents the professional textile care process as shown in fig. -1 [2]. In all cases a cross through the symbol indicates 'do not' $[10]$.

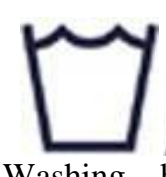

Washing

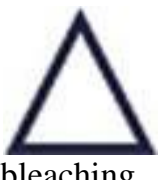

bleaching

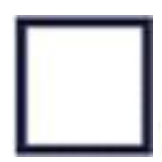

drying

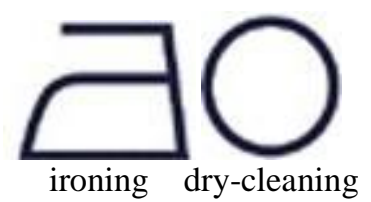

ironing dry-cleaning
Fig-1: Identification indices for care labelling

\section{MATERIALS AND METHODS}

In this case study, warp and weft yarns have been produced from the silk filaments procured from a commercial silk mill. The specifications of the yarns produced have been furnished in table-2.
Table: 2 Yarn specifications

\begin{tabular}{|l|l|l|l|}
\hline $\begin{array}{l}\text { Sl. } \\
\text { No. }\end{array}$ & $\begin{array}{l}\text { Yarn } \\
\text { Particulars }\end{array}$ & Warp Yarn & Weft Yarn \\
\hline 1 & Type & $\begin{array}{l}\text { Mulberry } \\
\text { filament } \\
\text { filature silk }\end{array}$ & Duppion silk \\
\hline 2 & $\begin{array}{l}\text { Count before } \\
\text { degumming }\end{array}$ & 2 ply 42 denier & $\begin{array}{l}2 \text { ply 220 } \\
\text { denier }\end{array}$ \\
\hline 3 & $\begin{array}{l}\text { Count after } \\
\text { degumming }\end{array}$ & 2 ply 34 denier & $\begin{array}{l}2 \text { ply 175 } \\
\text { denier }\end{array}$ \\
\hline 4 & $\begin{array}{l}\text { Twist per } \\
\text { metre }\end{array}$ & 700 & z-twist \\
\hline 5 & Twist direction & s-twist \\
\hline
\end{tabular}

The yarns produced have been subjected to arm-dyeing and the recipe of the dye bath has been provided in table- 3 .

Table: 3 Yarn dyeing recipe

\begin{tabular}{|l|l|c|}
\hline Stages & Chemicals & $\begin{array}{l}\text { Quantity } \\
\text { (gm/litre) }\end{array}$ \\
\hline \multirow{4}{*}{$\begin{array}{l}\text { Degumming } \\
\text { (M:L=1:17) }\end{array}$} & Stain removal agent & 2 \\
\cline { 2 - 3 } & Wetting agent & 1 \\
\cline { 2 - 3 } & Lubricating agent & 2 \\
\cline { 2 - 3 } & Degumming agent & 4 \\
\hline \multirow{3}{*}{$\begin{array}{l}\text { Bleaching } \\
\text { M:L=1:20) }\end{array}$} & Hydrogen peroxide $\left(\mathrm{H}_{2} \mathrm{O}_{2}\right)$ & $3-5$ \\
\cline { 2 - 3 } & Stabilizer & 1 \\
\hline \multirow{4}{*}{$\begin{array}{l}\text { Dyeing } \\
\text { M:L=1:20) }\end{array}$} & Levelling agent & 2 \\
\cline { 2 - 3 } & $\begin{array}{l}\text { Acetic acid as } \\
\text { controller }\end{array}$ & 2 \\
\cline { 2 - 3 } & Metal Complex Dye & $\begin{array}{l}\text { As per shade } \\
\text { depth }\end{array}$ \\
\cline { 2 - 3 } & Dye fixing agent & 4 \\
\hline \multirow{3}{*}{ Scrooping } & Acetic acid & 2 \\
\cline { 2 - 3 } & Anti-fungal agent & 3 \\
\cline { 2 - 3 } & Anti-static agent & 2 \\
\hline
\end{tabular}

The silk fabric woven from the dyed yarns have been specified in table- 4 and the particulars of the loom in which such fabric has been woven are provided in table- 5 .

Table: 4 Fabric specifications

\begin{tabular}{|l|l|l|}
\hline $\begin{array}{l}\text { Sl. } \\
\text { No. }\end{array}$ & Fabric property parameters & Values \\
\hline 1 & Weave construction & Plain weave \\
\hline 2 & $\begin{array}{l}\text { Thread density (ends/cm } \\
\text { picks /cm) }\end{array}$ & $48 \times 33$ \\
\hline 3 & Areal density (gsm) & 91.00 \\
\hline
\end{tabular}


Table: 5 Loom Particulars

\begin{tabular}{|l|l|l|}
\hline $\begin{array}{l}\text { Sl. } \\
\text { No. }\end{array}$ & Loom parameters & Details / Values \\
\hline 1 & Loom make & Dornier HTV \\
\hline 2 & Loom type & Rigid rapier \\
\hline 3 & Loom speed (ppm) & 400 \\
\hline 4 & Reed space $(\mathrm{cm})$ & 140 \\
\hline 5 & Reed air space $(\%)$ & 60 \\
\hline 6 & Warp tension & $10 \mathrm{cN} /$ thread \\
\hline 7 & Crossing angle (degrees) & 325 \\
\hline
\end{tabular}

In the present study, the quality related property parameters like colour change, colour staining, dimensional changes and ironing of the woven silk fabric sample have been analyzed and evaluated to formulate and establish its appropriate care instruction.

Colour fastness to washing is a common quality parameter, which is considered very important from the point of view of consumers. This test determines the loss and change of color in the washing process and the possible staining of other garments. The most common test methods that are generally followed for colour fastness are ISO: 105 C06:1994.

Woven silk fabric of size $4 \times 10 \mathrm{~cm}$ has been washed as per the method ISO: 105 C06:1994, A2S. In this method, the fabric sample is stapled with undyed grey silk fabric on one side of the former and grey cotton fabric on the other side to check the staining of the sample against the grey silk and cotton fabrics. This complies with the relevant section F01 to F08 of ISO 105-F:1985 which states that one of the adjacent fabrics shall be made of the same kind of fibre as that of the textile to be tested and the second piece made of the fibre cotton as specified [11]. Washing has been carried out in a standard Launderometer. The shaft and container assembly of the launderometer is rotated at a frequency of $40 \mathrm{rpm}$, setting the temperature of the container liquor at $40^{\circ} \mathrm{C}$. The temperature is controlled thermostatically. $4 \mathrm{gm}$ per litre of ECE detergent and $1 \mathrm{gm}$ per litre of Sodium perborate have been used here for washing. Ten small stainless steel balls of diameter $6 \mathrm{~mm}$ each were used to facilitate agitation during washing. The woven silk fabric sample has been treated in the above condition for 30 minutes to observe colour change and staining behavior of the sample.

Colour fastness to commercial dry-cleaning using perchloroethylene is normally used in the case of textiles that are sensitive to aqueous medium, like silk fabrics. The test method which is generally followed is ISO105 DO1. In this method, complying with ISO 105-F01-07, the dyed silk fabric sample has been placed inside a bag whose two sides are undyed grey cotton and grey silk fabrics of dimension $100 \mathrm{~mm} \times 100 \mathrm{~mm}$ sewn together. For proper agitation of the dyed silk fabric sample during rotation of the launderometer shaft, 12 non-corrodible steel discs of mass $20 \mathrm{gm} \pm 2 \mathrm{gm}$ each have been inserted in the sewn bag. The dry-leaning of the silk fabric sample has been carried out at $30^{\circ} \mathrm{C}$ for 30 minutes. Comparative analysis of the test results of colour change and colour staining of the dyed fabric samples during washing and dry-cleaning have been tabulated in tables 6 and 7 respectively.

A common concern in apparel performance characterization is its dimensional stability. Dimensional changes of fabrics when subjected to home laundering procedures following AATCC 135-2004 test standard are measured using pairs of benchmarks applied to the fabric before laundering. The test method AATCC 158-2005 is followed for the determination of dimensional change of fabrics and garments after dry cleaning in perchloroethelyne. The test results showing notable dimensional changes of the fabric samples have been provided in table 8 .

\section{RESULTS AND DISCUSSIONS}

\subsection{Colour Change}

Colour change values of four number of fabric samples against washing and dry cleaning are given in table-6. From the values it has been observed that for light shades colour change values assessed by grey scale after washing is $4 / 5$ and that after dry cleaning is 5 . The values signify that almost no change has occurred in the dyed fabric samples in both the cases. But for dark shaded fabric samples the colour change values observed after washing and dry cleaning are $3 / 4$ and 5 respectively. The values signify that slight colour change had occurred for the fabric samples after washing whereas no colour change had occurred after dry cleaning.

Table: 6 Colour changes of the dyed fabric samples observed under different methods

\begin{tabular}{|l|l|c|c|}
\hline $\begin{array}{l}\text { Sample } \\
\text { No. }\end{array}$ & Shades & $\begin{array}{l}\text { Colour change } \\
\text { values against } \\
\text { Washing }\end{array}$ & $\begin{array}{l}\text { Colour change } \\
\text { values against } \\
\text { Dry cleaning }\end{array}$ \\
\hline 1 & Light shade & $4 / 5$ & 5 \\
\hline 2 & Light shade & $4 / 5$ & 5 \\
\hline 3 & $\begin{array}{l}\text { Dark shade } \\
\text { (navy) }\end{array}$ & $3 / 4$ & 5 \\
\hline 4 & $\begin{array}{l}\text { Dark shade } \\
\text { (green) }\end{array}$ & 4 & 5 \\
\hline
\end{tabular}

\subsection{Colour Staining}

Colour staining values after washing and dry cleaning of the fabric samples against the adjacent undyed silk and cotton fabrics have been provided in table-7. The values reveal that light shaded fabric samples show no colour staining to adjacent grey silk and cotton fabrics after washing and dry cleaning. Amongst the dark shaded fabric samples, navy shade shows a value of 2 in the grey scale which signifies that a considerable colour staining has taken place against both the adjacent silk and cotton fabrics. This poor value of colour staining of the dark shaded fabric sample is not at all acceptable by the buyers. The dry cleaning value of the same dark shaded fabric sample is found to be 5, signifying no colour staining. The green shaded fabric sample shows noticeable colour staining after washing whereas no such change in colour staining has been observed after dry cleaning. 
Table: 7 Colour staining of the dyed fabric samples observed under different methods

\begin{tabular}{|l|l|c|c|c|c|}
\hline $\begin{array}{l}\text { Sample } \\
\text { No. }\end{array}$ & Shades & \multicolumn{2}{|l|}{ After washing } & \multicolumn{2}{l|}{ After dry cleaning } \\
\hline & $\begin{array}{l}\text { Staining } \\
\text { to silk }\end{array}$ & $\begin{array}{l}\text { Staining } \\
\text { to } \\
\text { cotton }\end{array}$ & $\begin{array}{l}\text { Staining } \\
\text { to silk }\end{array}$ & $\begin{array}{l}\text { Staining } \\
\text { to } \\
\text { cotton }\end{array}$ \\
\hline 1 & $\begin{array}{l}\text { Light } \\
\text { shade }\end{array}$ & 4 & 4 & 5 & 5 \\
\hline 2 & $\begin{array}{l}\text { Light } \\
\text { shade }\end{array}$ & 4 & 4 & 5 & 5 \\
\hline 3 & $\begin{array}{l}\text { Dark } \\
\text { shade } \\
\text { (navy) }\end{array}$ & 2 & $2 / 3$ & 5 & 5 \\
\hline 4 & $\begin{array}{l}\text { Dark } \\
\text { shade } \\
\text { (green) }\end{array}$ & $3 / 4$ & $3 / 4$ & 5 & 5 \\
\hline
\end{tabular}

\subsection{Dimensional Changes}

Dimensional changes of the fabric samples after home laundering are found to be very high (7\% shrinkage in the warp direction) than the maximum acceptable limit of apparel trade market standard (both for US based and non US based). Whereas dimensional changes of the fabric samples after dry cleaning are found to be well within the limit of acceptance of the market standard. Overall appearance of the washed silk fabric samples was not satisfactory. Occurrence of creases, crumples and wrinkles marked the fabric surface. While there was no such occurrences found in the dry cleaned fabric sample. The appearance of the dry cleaned fabric sample was observed to be quite smooth without any fuzziness or pilling.

Table: 8 Dimensional changes (shrinkage \%) of the fabric samples after washing and dry cleaning

\subsection{Ironing}

\begin{tabular}{|l|l|l|l|l|}
\hline \multirow{2}{*}{$\begin{array}{l}\text { Observa- } \\
\text { tions }\end{array}$} & \multicolumn{3}{|l|}{$\begin{array}{l}\text { Dimensional changes } \\
\text { of silk fabrics on } \\
\text { home laundering } \\
\text { (AATCC 135-2004) }\end{array}$} & $\begin{array}{l}\text { Dimensional changes } \\
\text { of silk fabrics on } \\
\text { Dry cleaning } \\
\text { (AATCC 158-2005) }\end{array}$ \\
\cline { 2 - 5 } & $\begin{array}{l}\text { Along } \\
\text { warp } \\
\text { weft }\end{array}$ & $\begin{array}{l}\text { Along } \\
\text { warp }\end{array}$ & $\begin{array}{l}\text { Along } \\
\text { weft }\end{array}$ \\
\hline $\begin{array}{l}\text { Normal } \\
\text { cycle / } \\
\text { line dry }\end{array}$ & $-7 \%$ & $-1.75 \%$ & $0 \%$ & $-1.25 \%$ \\
\hline
\end{tabular}

Selecting the appropriate temperature for ironing silk clothing can make the difference between ease and disaster. The right temperature selection will make ironing easier and quicker. The wrong temperature can mean a burn hole. Ironing of fabric on the wrong side or using a dummy cloth on the right side is always beneficial and it avoids the shining mark. When ironing silk, it should be remembered that no water should come in contact with the fabric. Presence of moisture may cause rings and spots in the silk fabric. On the other hand, too much heat may ruin the fabric. The recommended temperature for ironing silk fabric is "cool iron" or "low iron marked with a single dot" where the temperature should not exceed $110^{\circ} \mathrm{C}$.

\section{CONCLUSIONS}

Silk garments are no longer limited to high-end designer labels or neckties. Everyday silk casual wear for men and women are very popular. It drapes, looks and feels great. But, like other fabrics, silk is susceptible to conditions of wear, stains and color loss. The above study shows that silk responds well to dry cleaning than washing. It has been revealed from this study that washing of silk garments result in shrinkage, limpness, staining and considerable fading on dark shade. Therefore, it can be concluded that the recommended care code of silk items should be as follows -

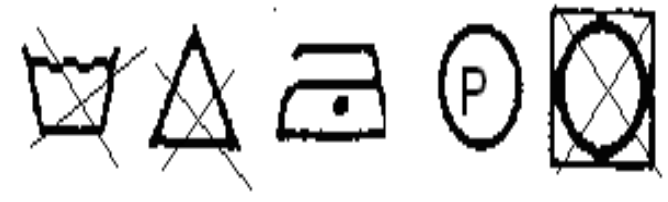

Do not wash; Do not bleach; Iron at low temperature; Professional dry cleaning; Do not tumble dry.

\section{ACKNOWLEDGEMENTS}

The authors extend their whole hearted gratitude to a reputed commercial Silk Mill, West Bengal, India for the full support and co-operation to carry out this work. The authors are also indebted to the Hon'ble Vice Chancellor and Pro Vice Chancellor, University of Calcutta for their valued consent to get this work published in this scholarly journal.

\section{REFERENCES}

[1]. http://textilelearner.blogspot.in/2012/02/internationalcare-labeling-code.html.

[2]. Annual Book of ASTM Standards. 2006. Vol -07.01, D5489.

[3]. Das, S. 2005. Indian Text J, CXV (6):84-87.

[4]. Intertek Testing Services Hong Kong Ltd. 1998. International Apparel, Buyers Quality Guide. $4^{\text {th }}$ Edition. 79-82. Hong Kong

[5]. 16 CFR 423. 2013 Care Labelling of Textile Wearing Apparel and Certain Piece Goods as amended. A Guide to United States Apparel and Household Textiles Compliance Requirements US Dept of Commerce: 10-12.

[6]. Das, S. 2008. Indian Silk J, 47(1): 19-21.

[7]. http://www.fabindia.com/intl/fabric-care/

[8]. Wentz, M. 1996.Textile Care Technology Spectra and Care Labeling Issues, Apparel Care and Environment Session, Washington, DC: 83-85.

[9]. Das, S. 2009. Quality characterization of apparel (Woodhead publishing Ltd.): 113.

[10]. Saville, B.P. 2000. Physical testing of textiles (Woodhead publishing Ltd):304

[11]. Indian Standard Textile. 1994. Tests colour fastness Part C06 IS/ISO 105-C06, New Delhi. 